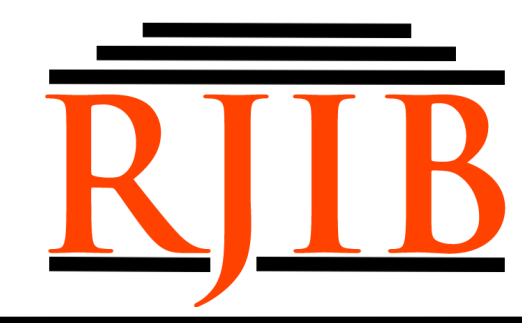

RETORIKA: Jurnal Ilmu Bahasa

Vol. 4, No. 2 Oktober 2018, Page 171-180

P-ISSN: 2406-9019

E-ISSN: 2443-0668

Available Online at https://ejournal.warmadewa.ac.id/index.php/jret

\title{
Balinese Language Usage by Ethnic Bali Teens in Dangin Puri Village, East Denpasar Subdistrict, Denpasar City
}

\author{
Ni Putu Geasha Pusvika Devi and Ni Wayan Kasni
}

\section{Magister of Linguistic, Universitas Warmadewa, Denpasar, Bali, Indonesia}

geacassiopeia@gmail.com

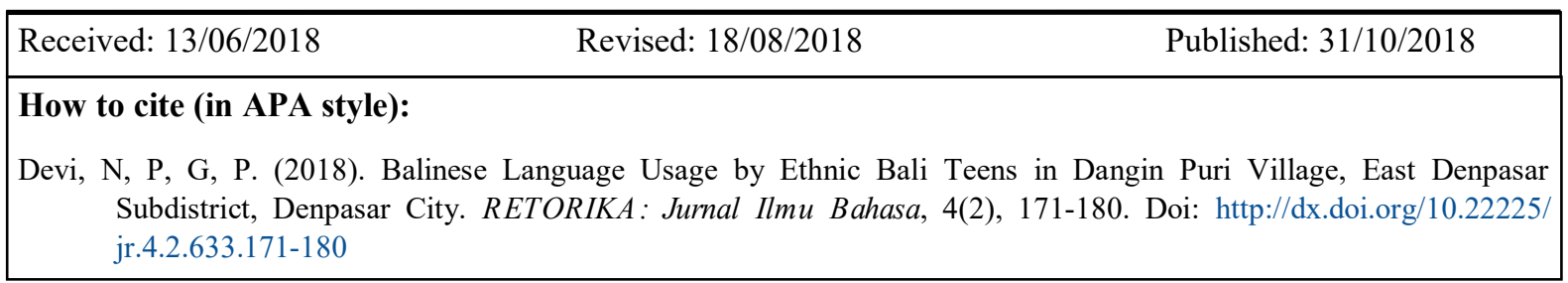

\begin{abstract}
This study examines the use of Balinese language by ethnic Balinese teenagers based on the language use domains that have been determined by the author, and also the factors that influence the use of Balinese language by ethnic Balinese teenagers in the village of Dangin Puri, East Denpasar district, Denpasar City. The method used in this research is qualitative and quantitative method. This research data in the form of primary data taken from the field in the form of the use of the language of Bali by teenagers, and secondary data in the form of writing data obtained from the questionnaire. The results of this study indicate that the use of Balinese language by ethnic Balinese teenagers in the village of Dangin Puri based on four domains that have been determined that the family, the neighborhood, the domain of education, and the domain of religion are still quite high. Factors influencing the use of Balinese language by ethnic Balinese teenagers are caused by internal factors that include self-factor, interaction factor in the family, and factor interaction with the environment and friends, then external factors that influence the condition of bilingual speakers, the factors of globalization, educational factors, and Indonesian factors.
\end{abstract}

Keywords: Domain; Ethnic Balinese Teenagers; Use of Language.

\section{INTRODUCTION}

Life and language can be characterized by worlds of digital strings. Just as genetic material influences living, people coordinate by acting to evoke 'words' (i.e. verbal types that people identify with physical wordings) (Cowley \& Markoš, 2018). The concept of language distance seems to be related to the process of language identification (Gamallo, Pichel, \& Alegria, 2017). Grammatical inference or automata learning is the problem of inferring a finite concise representation (usually an automaton) of a fixed yet unknown language L (Fisman, 2018). Learning two languages instead of one language might affect not only language acquisition and processing but also cognitive development, especially in the domain of executive functions (Goriot,
Broersma, McQueen, Unsworth, \& van Hout, 2018).

Being spoken to or being evoked in language, even at a distance, can have material effects and consequences for people and their relations with others (High, 2018). The internal linguistic factors refer to the structural traits of the grammar and lexicon of the target language, compared to the languages already known to the learner, i.e. his or her linguistic repertoire (Gobbo, 2017). Bilinguals often experience interference from the unintended language during daily communication (B. Li, Liu, Pérez, \& Xie, 2018). The language generated by a pattern is the set of strings that can be obtained from the pattern using some substitution (Hölzl, Jain, \& Stephan, 2018). Typicallydeveloping (TD) childrens' language acquisition is supported by general cognitive, 
social and perceptual skills (Mason-Apps, Stojanovik, Houston-Price, \& Buckley, 2018). Flow has been shown to play an important role in enhancing learning and language development in the foreign language classroom (C. Li, Jiang, \& Dewaele, 2018).

The language ideological perception of distinct language practices are, in part, dependent on the social identify of the person using the language, and the significance or meaning of an ideology can differ substantially for different subgroups or subject positioning (Henderson, 2017). Language shift is a cause of concern in the communities (Hauck, 2018). The aim of automatic language recognition is to identify the language being spoken from a group of possible languages (Irtza, Sethu, Ambikairajah, \& Li, 2018). Bilinguals frequently switch between their languages in daily life (de Bruin, Samuel, \& Duñabeitia, 2018).

Language is one of the tools used in daily communication. Basically, language has certain functions that are used based on one's needs.According to (Kridalaksana, 1982), language is an arbitrary system of symbolic sounds used by community members to cooperate, communicate, and identify. In fact, as a language communication tool can be a channel of formulation of intent and allows to create cooperation with others (Muksin, 2014).Bahasa Indonesia is the language of unity Indonesia is a Malay language used widely as a language lingua franca throughout the archipelago. The use of regional languages especially Balinese language amid the flow of globalization in the life of Balinese people influence the existence of the use of Balinese language if further eroded by the current globalization will be endangered. The development and progress of Indonesian language more quickly and thoroughly in every community, the use of the language of Bali gradually increasingly replaced with the Indonesian language, this tendency can trigger a shift in Balinese language, especially among ethnic Balinese teenagers. This phenomenon the authors found also among teenagers in the village of Dangin Puri, in the District of East Denpasar, Denpasar City, Bali Province. In Dangin Puri village, teenagers communicate using two different languages, namely Indonesian as the national language and official language, and the language of Bali as a local language and regional languages.

In the digital era, communicating findings of scientific research to the public has become easier and faster than ever before. Information reaches people almost $24 \mathrm{~h}$ a day through a number of channels, including mass media, the internet, social networks, and even smartphone chat groups (Cainzos-Achirica et al., 2018). A communication strategy should be included from the outset to guarantee quality and smooth implementation of the intervention (Ohlrogge \& Suggs, 2018) An online survey of college students was conducted to investigate the relationship between family communication patterns and financial literacy (Hanson \& Olson, 2018). By the same logic, public relations and communication executives at the helm of crisis management stand to gain insight from the lessons learned during this most recent crisis and the ones preceding it (particularly the Great Depression) (Jin et al., 2018). Bargaining is an interesting setting to examine the role of communication in economic interactions (Brunner \& Ostermaier, 2018) The extensive use of reputation and communication systems makes it crucial to understand the effect of introducing communication to markets, and how modifications to mechanisms can improve efficiency (Raszap Skorbiansky, 2018).

In this regard, the authors are interested in raising the phenomenon of Balinese language use by ethnic Balinese teenagers in Dangin Puri village for further study which can then be used as an effort to foster and preserve Balinese language and can be useful as a benchmark for researchers interested in examining the Balinese language in terms of sociolinguistics. Research the use of Balinese language by ethnic Balinese teenagers using sociolinguistic theory to analyze data and phenomena that exist among teenagers, especially ethnic Balinese. In this study the theory used refers to sociolinguistic theory that studies about the use of language. The theory used in this study are language selection, bilingualism, and factors influencing language.

\section{METHODS}

In this study the researcher chose to use 2 research method that is qualitative approach that is research which use descriptive data in the form of written data and oral data obtained from observation of research subject and using quantitative approach that is to determine the percentage of choice of language by ethnic Balinese teenager in Kelurahan Dangin Puri, Denpasar. This qualitative and qualitative approach which in its implementation will be used sequentially. 


\section{DISCUSSION}

The use of language by bilingual involves choice of language used in certain situations, places, and topics. In this study the use or selection of Balinese language by teenagers in the village of Dangin Puri, Denpasar restricted to the domains of family, neighborhoods, education, religion.

\section{The use of the Balinese Language In The Family Domain}

In the domain of families with home background and the use of language in verbal interactions involving actors said family members such as father, mother, brother, and other relatives. In this domain the acquisition of the mother tongue of Bali has an average of $94 \%$ of respondents learn to speak Balinese from parents in the environment.

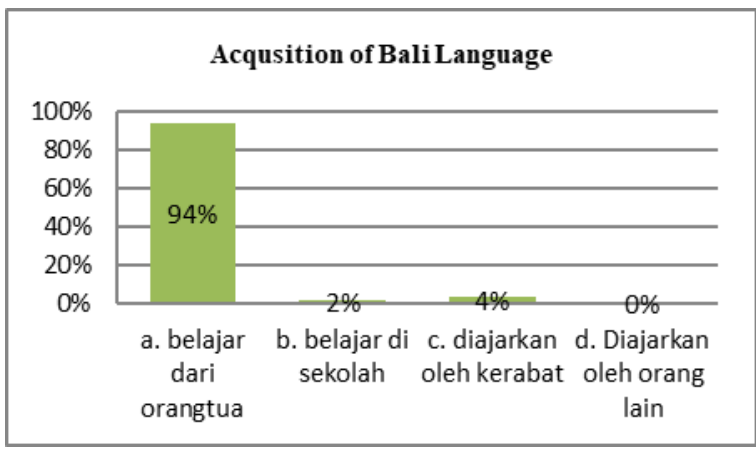

Figure 1 Acquisition of Bali Language

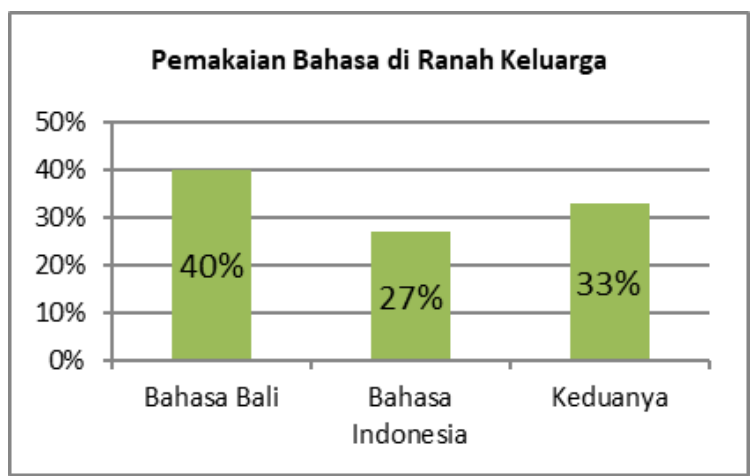

Figure 2 Language Use in Family

In Figure 2 the situation indirectly makes respondents prefer to use the language of Bali than the Indonesian language as a means of communication in the family environment. In the Figure 2 below found that $40 \%$ of respondents use Balinese language, $27 \%$ of respondents use Indonesian language and 33\% use Balinese and Indonesian language in language use in the family domain. The ethnic Balinese teenager said that the father, mother and brother are used as indicators in the assessment of the percentage of the use of Balinese language in the family environment.
In Figure 3 bellow is the result of observations of the use of Balinese language respondents with fathers spoken partners obtained the percentage of the use of Balinese language by $56 \%$ the use of the Balinese language at any time, $37 \%$ occasionally use Balinese, $5 \%$ of respondents rarely use Balinese, and $2 \%$ of respondents answered very rarely using Balinese in speech events.

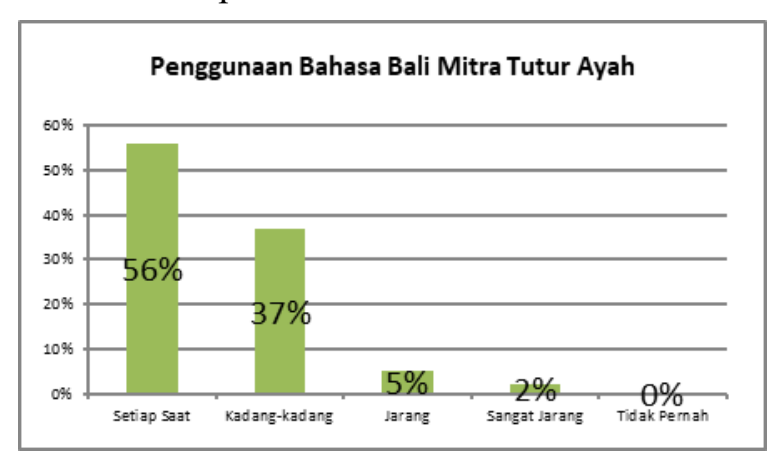

Figure 3 Use of Balinese Language Partner Father's

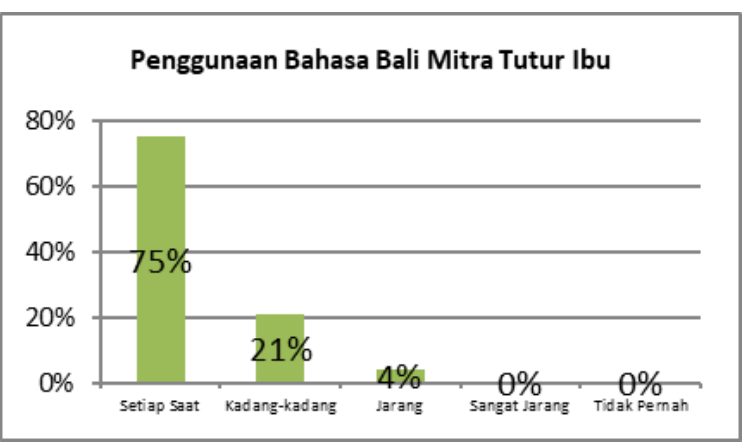

Figure 4 Use of Balinese Language Partner Mother's

In Figure 4 it is known that the percentage of Balinese language usage with mother counterpart gets $75 \%$ of respondents using Balinese at all times, $21 \%$ answered using Balinese sometimes and $4 \%$ of respondents seldom use Balinese language in speech events. Here are the results of observing the use of Balinese language with brother

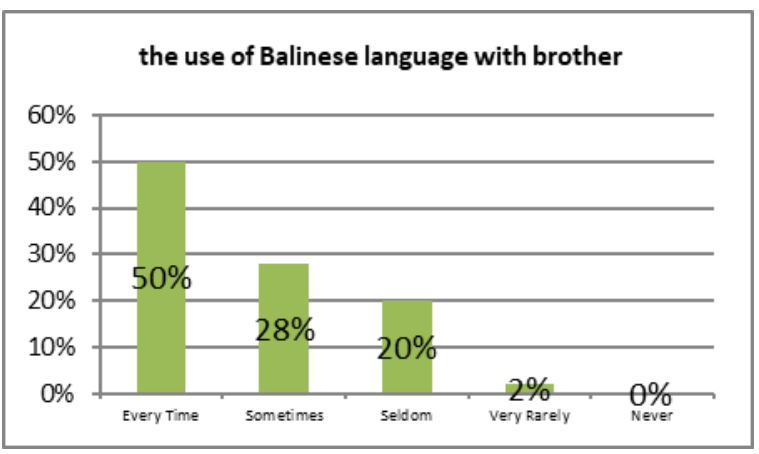

Figure 5 Use of Balinese Language Partner Brother's From the above observations, it is known that the use of Balinese language is $50 \%$ of Balinese teenagers use Balinese language every time, $28 \%$ use Balinese sometimes, 20\% 
seldom choose, and $2 \%$ choose very rarely using Balinese language. Of the three partners said it can be concluded that the average percentage of the use of Balinese language in the family domain is $61 \%$ of teenagers choose to use Balinese language "very often", $28 \%$ chose to use Balinese "sometimes", 10\% answered using Balinese language " rare ", and $1 \%$ of respondents chose very rarely using the Balinese language.

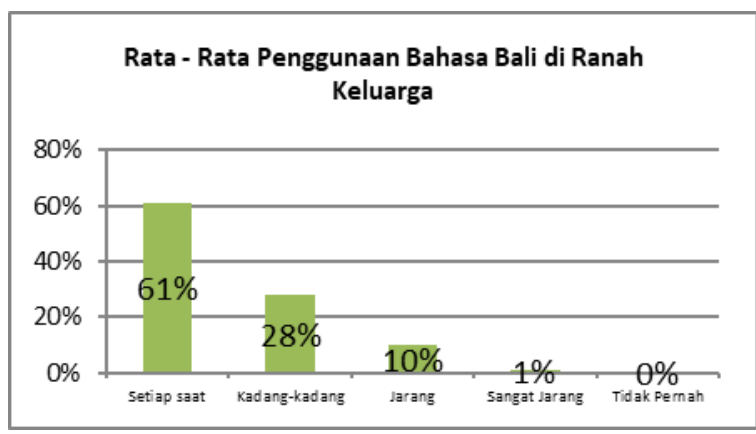

Figure 6 Average Use of Balinese Language in Family the overall indicator of the spokesperson used as a benchmark of the use of Balinese language in the family domain of Balinese ethnic teenagers in the village of Dangin Puri, Denpasar City is known that $61 \%$ of Balinese ethnic teenagers respondents choose "every time" using Balinese language is still very high in the family environment as a means of communication in family domain, this situation must be maintained for the next generation of mother tongue is the Balinese language among ethnic Balinese teens in the city of Denpasar.

\section{The Use Of The Balinese Language In The Neighboring Domain}

The choice of language in the domain of neighborhood meant to get an idea of the use of language by ethnic Balinese teenager when making a verbal communication with neighbors in their neighborhood. From the results of observations obtained information that ethnic Balinese teenagers adolescents still use the language of Bali as a means of communication in this area of neighborliness. From the above statement can be seen the percentage of teenagers of Bali ethnic who use the language of Bali in the area of neighboring $54 \%$, teenagers who chose to use the Indonesian language by $28 \%$, and who chose to use the language of Bali and the Indonesian language of $18 \%$.
Pemakaian Bahasa Bali Dalam Ranah Ketetanggaan

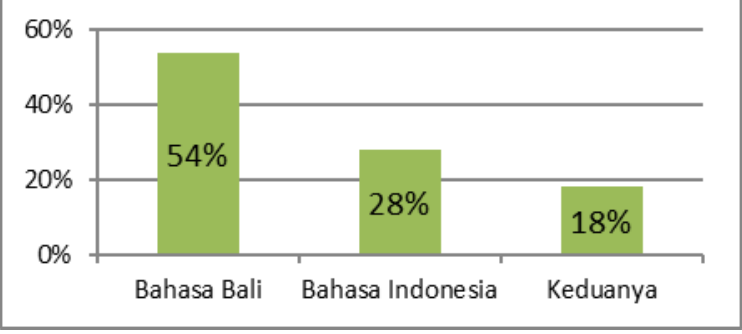

Figure 7 Use of Balinese Language in the Neighborhood Area

Penggunaan Bahasa Bali dengan Mitra Tutur Tetangga Sebaya

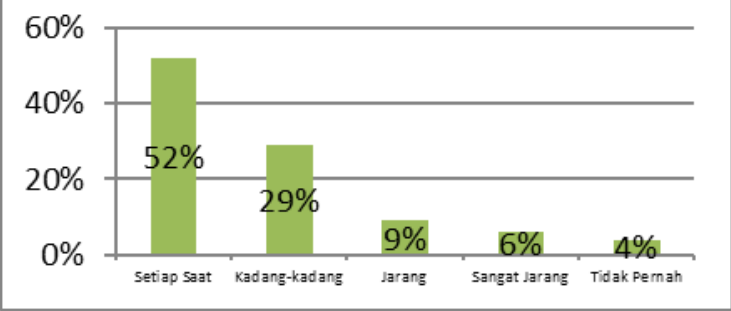

Figure 8 Use of Balinese Language with Partner Speech Peers

Can be concluded from total ethnic Balinese teenagers as many as 180 respondents there are more than 90 people who still use the language of Bali in communication in neighboring domain. In this area, there are 3 (three) speech partners who are used as indicators in assessing the percentage of use of the Balinese language namely peer neighbors, older neighbors, and younger neighbors. When ethnic Balinese teenagers in village Dangin Puri gather with peer neighbors, they mostly use Balinese language in communicating. Here is the percentage of the use of Balinese language with the neighbor's said partner. In Figure 8 , it can be seen that the percentage of Balinese language use is $52 \%$ of respondents choose to use Balinese language at all times, $29 \%$ of respondents seldom use Balinese language, $9 \%$ respondents rarely use Balinese language, $6 \%$ of teenage Balinese respondents choose very rarely use Balinese language, and $4 \%$ of respondents stated that they never use Balinese language in the neighbor area of neighboring friends. The percentage of the use of Balinese language with older neighboring partners is very different from the percentage of the use of Balinese language with the neighbors' said above. The difference can be seen in the Figure below. 


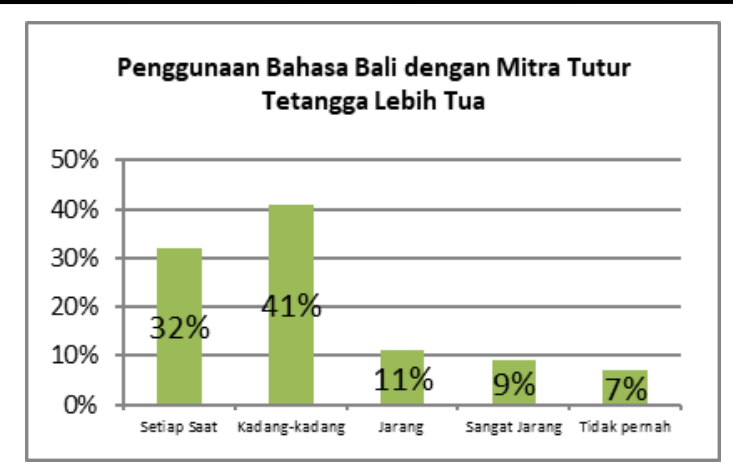

Figure 9 Use of Balinese Language with Partner Speech of Older Neighbors

Penggunaan Bahasa Bali dengan Mitra Tutur Tetangga Lebih Muda

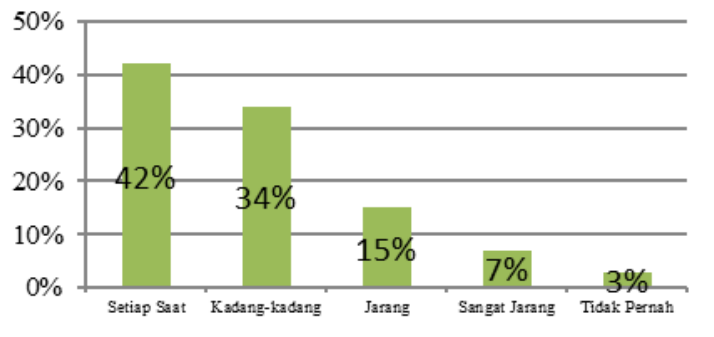

Figure 10 Use of Balinese Language with Partner Speech of Younger Neighbors

Figure 9 is the result of the respondent's answer about the use of Balinese language with the older neighbor's said partner get the percentage of $32 \%$ stated every time using the Balinese language, $41 \%$ of respondents said sometimes using the Balinese language on older neighbors say $11 \%$ using the language of Bali, $9 \%$ of respondents very rarely use the language of Bali, and 7\% of teenagers claimed never to use the Balinese language on older neighbors said. This is due to the psychological factors of adolescents when talking to older neighbors, where they have to talk and pay attention to decency. Known from the observations found that there is a tendency of teenagers more comfortable using the Indonesian language to avoid the mistakes of speech or irrational speaking in Balinese language especially Balinese subtle. In the use of Balinese language with neighbors said the younger researchers get more varied answers to the language of Bali. The results of the questionnaire can be seen in Figure 10, there are $42 \%$ of respondents comfortable using the Balinese language at any time, $34 \%$ of respondents answered sometimes speaking Balinese, $15 \%$ of teenagers seldom choose to use Balinese language, $7 \%$ choose very rarely use Balinese language, and $2 \%$ of respondents said they never used Balinese language in their younger neighbors' counterparts. When Balinese teenagers communicate verbally with younger neighbors or in this case children, the communication process that occurs is informal, making it easier for ethnic Balinese teens to communicate with the language of Bali. In addition, the factors that make the percentage of $7 \%$ of respondents very rarely use the language of Bali, caused by the phenomenon of the environment of young families who tend not to use the language of Bali as the mother tongue or first language children in the family environment.

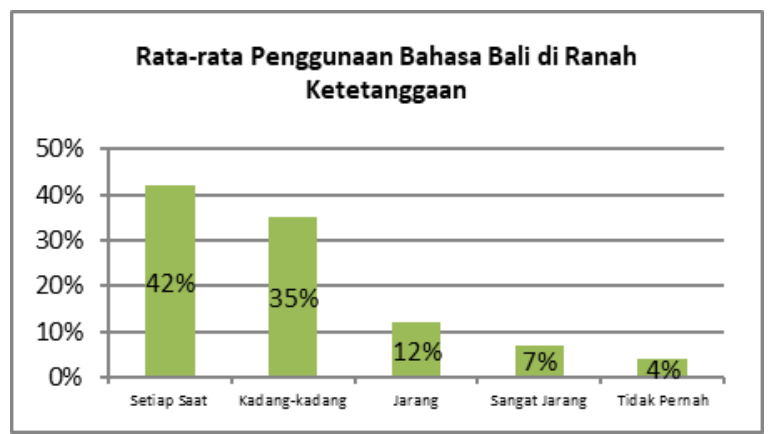

Figure 11 Average Use of Balinese Language in the Neighborhood Area

Overall, it was found that the average use of Balinese language by Balinese ethnic teenagers in Dangin Puri Village was $42 \%$ using Balinese at all times, $35 \%$ of respondents used Balinese sometimes, $12 \%$ seldom chose, $7 \%$ of respondents said very rarely use Balinese language, and $4 \%$ of respondents chose never to use Balinese language in neighboring domain. Based on the three indicators of an event, the speech factor of the spokesperson greatly influences the use of Balinese language, and other influencing factors are various situations, speech topics or speech objects can also affect the use of language by ethnic Balinese teenagers in neighboring domain.

\section{The Use Of The Balinese Language In The Education Domain}

The development of the era many give positive and negative influence in science and technology and social culture of society. The influence also occurs in communities throughout Indonesia. This situation spurred the people of Indonesia, especially ethnic Balinese teenagers in the urban village of Dangin Puri, Denpasar to continue to follow the development of science and technology is growing rapidly. When educated, indirectly ethnic Balinese teenagers received a second language acquisition of the Indonesian language used as the language of instruction by teachers or faculty in the learning process. This situation continues as they interact with teachers, employees / messengers, and 
classmate in the domain of education. The following recapitulation of the answer to the use of Balinese language of 180 respondents obtained information that $8 \%$ of respondents chose to use the language of Bali, $53 \%$ chose to use the Indonesian language, and 39\% chose to use both languages by looking at variable partners said, object or topic of the speech.

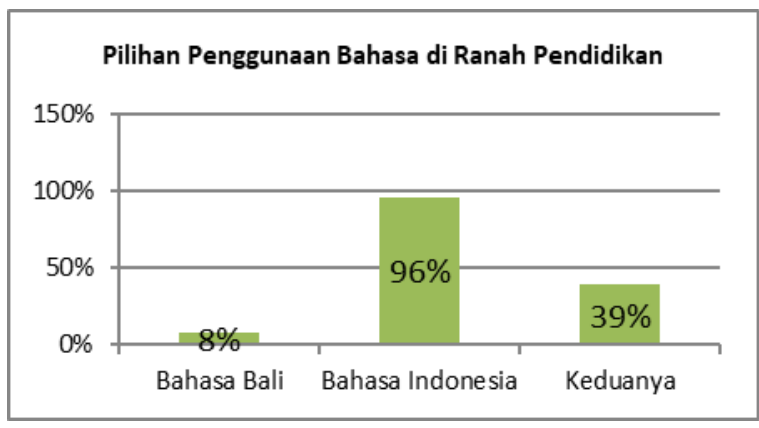

Figure 12 Choice of Language Use in the Field of Education

In this research, the researcher uses 3 (three) spoken partners to be used as an indicator of the intensity assessment of Balinese language use by Balinese ethnic teenagers, teachers/ educators, clerks / employees and classmates. One of the partners said in the domain of education is a classmate of ethnic Balinese teenagers. When they interact in informal situations so that communication takes place regardless of language level.

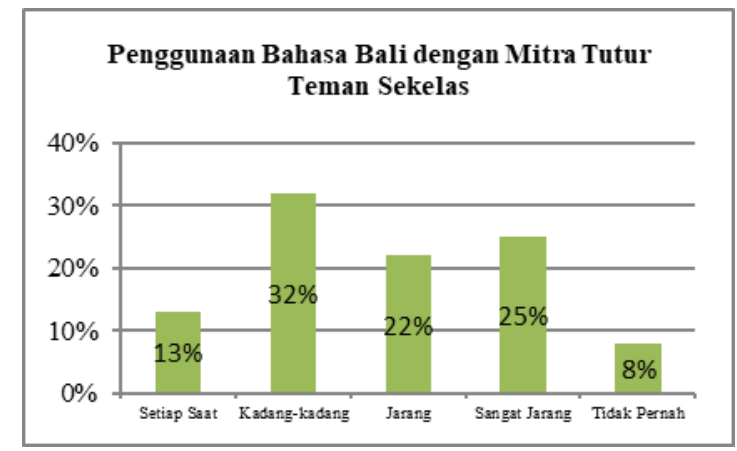

Figure 13 Use of Balinese Language with Classroom Speech Partners

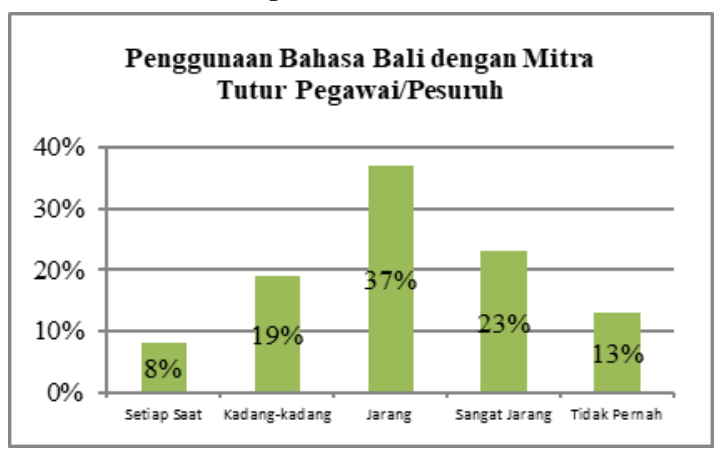

Figure 14 Use of Balinese Language with Employee Tutur Partner
Can be viewed on the 13th Figure above the results of the respondent's answer answered $13 \%$ of respondents use Balinese language, $32 \%$ of respondents chose occasionally using Balinese language, $22 \%$ of Balinese ethnic respondents answered rarely using Balinese language, $25 \%$ and $8 \%$ of respondents said they never use Balinese language in the domain of education with partners said classmates. Other ethnic Balinese teenagers in the education field are employees / clerk who work in school. Below is the result of recapitulation percentage of questionnaire answers from respondents for the use of Balinese language by ethnic Balinese teenagers with

partners said employee / clerk. From the Figure 14 can be seen the percentage of selection of Balinese languages was very low, amounting to $8 \%$, then $19 \%$ of respondents chose sometimes use the language of Bali, 37\% of respondents rarely use the language of Bali, $23 \%$ of respondents teens choose very rarely, and $13 \%$ of respondents answered never using Balinese language. This can be due to the verbal communication situation between ethnic Balinese teenagers and partners said in a formal context that requires ethnic Balinese teenagers to pay attention to the decency factor. The situation will also occur when ethnic Balinese teenager communicate with educators. They will choose to use the Indonesian language to communicate because they feel when talking to educators is a formal situation that takes into account the decency factor.

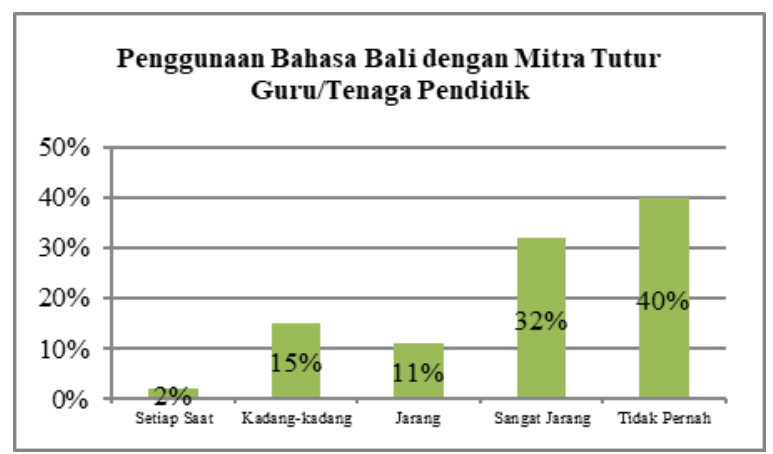

Figure 15 Use of Balinese Language with Teacher's Speech Partners / Educator Personnel

In the above Figure we can see that $2 \%$ of respondents responded to the use of Balinese at any time, $15 \%$ of respondents chose occasionally to use Balinese, $11 \%$ said rarely using Balinese, $32 \%$ chose very rarely in Balinese, and $40 \%$ of respondents of ethnic Balinese teenagers answered never use Balinese language with teacher / educators. 


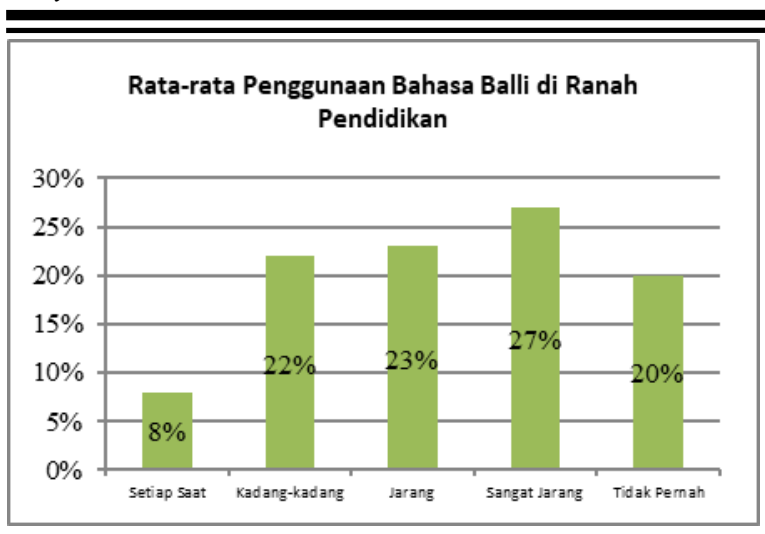

Figure 16 Average Use of Balinese Language in the Field of Education

Of the three categories of Balinese teenagers ethnicity speakers it can be concluded that the use of Balinese language in the educational domain earns a value that only $8 \%$ of respondents chose to use Balinese at any time, $22 \%$ of respondents chose to sometimes use Balinese, 23\%, 27\% of teenagers chose very rarely using Balinese language, and 20\% of respondents chose never to use Balinese. The high intensity of Indonesian use has a significant impact. If this continues and there is no effort from all parties to preserve the Balinese language then the next generation will have a very low quality and quantity of Balinese language.

\section{The Use Of The Balinese Language In The Religion Domain}

The domain of religion is the last domain of observation by researchers. Religious activities become one of the activities that must be done by ethnic Balinese teenagers in life. Many religious activities involve ethnic Balinese teenagers in their routines and characterize ethnic Balinese adolescents. The Figure below is the result of the observation of respondents to know the language of instruction used in religious activities.

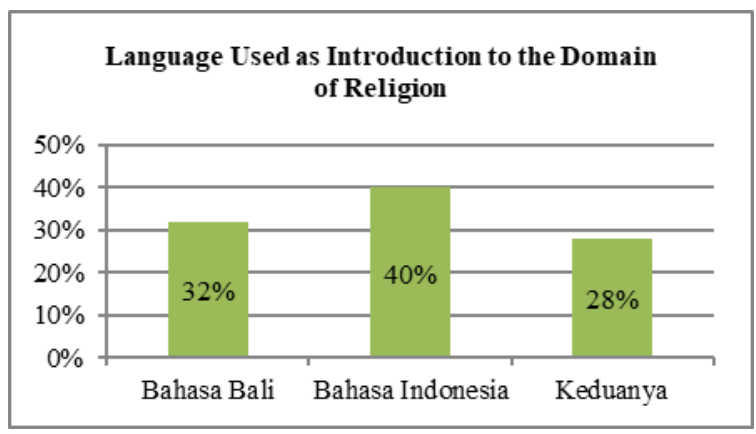

Figure 17 Languages Used as Introduction to the Domain of Religion

Based on Figure 17 above, it is found that the use of Balinese language is only $32 \%$, while the use of Indonesian language is $40 \%$, and the mixture of the use of Balinese and Bahasa Indonesia is $28 \%$. In the field of religion of the said partners will be divided into 3 (three) namely peer group said, older group, and younger group said the group. In the religious domain, there were answers of respondents' questionnaires from peer group responses by $23 \%$ of respondents answered every time, then $29 \%$ answered occasionally, $16 \%$ respondents said they rarely use Balinese, $21 \%$ said very rarely, and $11 \%$ answered never using Balinese. The result of the questionnaire is not much different from the speech that happened between ethnic Balinese teenagers with the older group. The statement was reinforced by the results of the respondents' recapitulation that stated that $22 \%$ stated every time using the Balinese language, $30 \%$ of respondents answered sometimes using Balinese language, $17 \%$ rarely answered, $22 \%$ answered very rarely, and 9\% said they never used Balinese language to the older group's spoken counterparts. For more details, see the Figures 18 and 19 below.

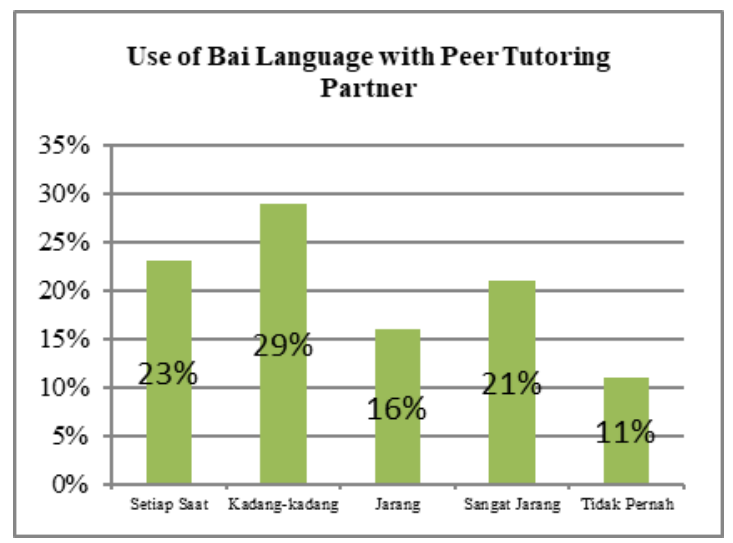

Figure 18 Use of Bali Language with Peer Tutoring Partner

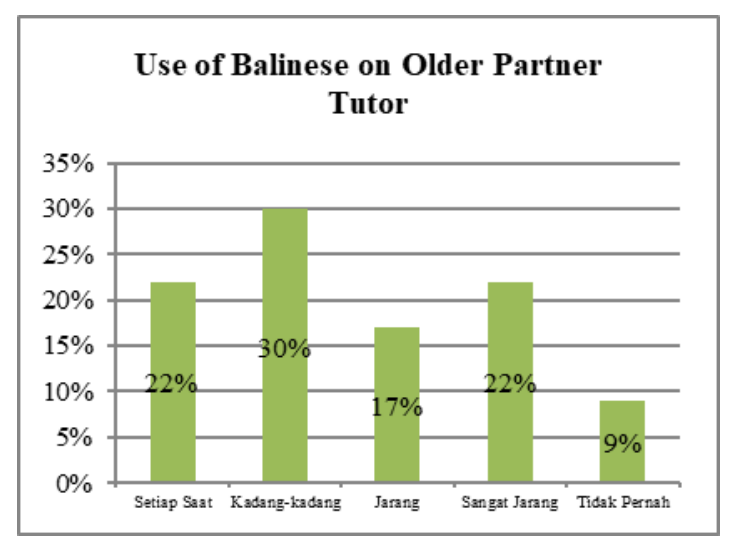

Figure 19 Use of Balinese on Older Partner Tutor

Likewise with the event said that happened between ethnic Balinese teenagers with the younger group said the group. Here are the results of the recapitulation of the 
respondents' answers stated that $17 \%$ of respondents answered every time using the Balinese language, $32 \%$ answered occasionally, $14 \%$ respondents teenagers answered rarely, $20 \%$ respondents answered very rarely, and $17 \%$ of respondents answered never use Balinese language.

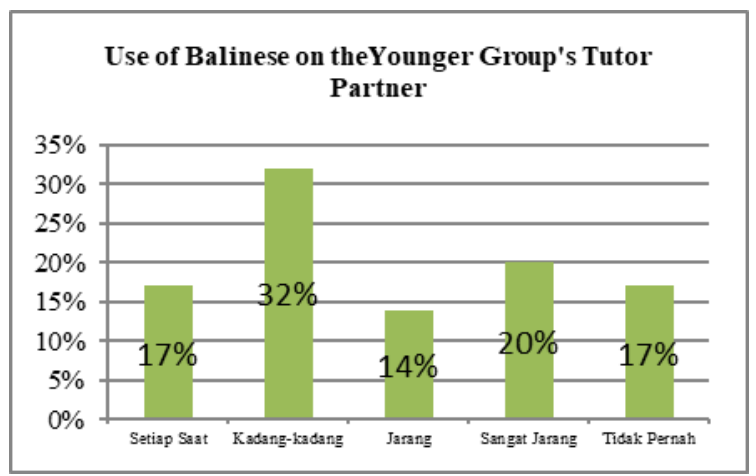

Figure 20 Use of Balinese on the Younger Group's Tutor Partner

Based on 3 (three) categories of youth adolescent ethnic Balinese counterparts can be concluded in the use of the language of Bali in the religious domain obtained a percentage of $21 \%$ of respondents using the Balinese language at all times, $30 \%$ of respondents teenagers sometimes, $16 \%, \quad 21 \%$ of respondents answered rarely using Balinese language, $21 \%$ of respondents answered very rarely, and $12 \%$ of Balinese ethnic respondents answered that they never use Balinese language in religion domain.

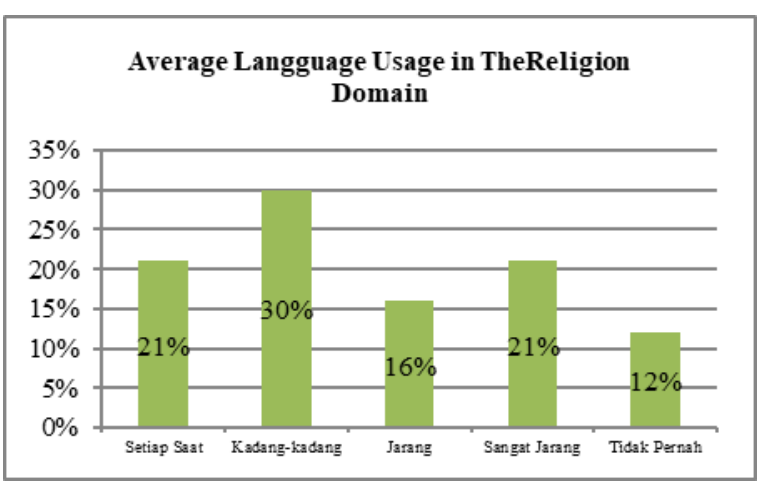

Figure 21 Average Language Usage in the Religion Domain

Factors Affecting the Use of Balinese Language by Ethnic Bali Teens in Dangin Puri Village, East Denpasar Subdistrict, Denpasar City

Internal factors

\section{a. Self Factor}

The self factor is a decrease in the quality and quantity of Balinese language in some domains influencing the existence of Balinese language among Balinese ethnic teenagers in communicating.

b. Interaction Factors in the Family

Family participation in influencing the use of the Balinese language is necessary to maintain loyalty in the use of the Balinese language despite receiving so much influence from outside the family sphere

c. Factors of Interaction with the Environment and Friends

The social interactions of ethnic Balinese teenagers with the environment of friends and the surrounding environment affect the use of the ethnic language of Balinese.

\section{External Factors}

\section{a. Condition of Bilingual Speaker Society}

The circumstances surrounding friends and within the family as a spoken partner of the ethnic Balinese are able to speak in addition to the language of Bali, the Indonesian language is also in use as a language of instruction in the realm of education and also the realm of religion. Therefore the condition of people who can speak more than one language or bilingual can affect the use of language by ethnic Balinese teenagers in the village of Dangin Puri.

b. Globalization Factor

The current era of globalization has encouraged speakers of a language to communicate and interact with speakers of other languages originating from other countries, especially English-speaking countries; in other words, the use of English as a globally accepted means of communication has a the process of using language.

c. Educational Factors

In the realm of education was introduced Indonesian language. From the acquisition of the second language is to form ethnic Balinese teenagers become dwibahasawan. The range of formal education background atmosphere in the speech events to make ethnic Balinese teenagers choose to use the Indonesian language.

\section{d. Factor of Indonesia}

the Indonesian language is used as a medium of intent which has a very strong influence to make ethnic Balinese teenagers more comfortable using Indonesian language than Balinese when talking with partners said without fear of background of the said partner.

\section{CONCLUSION}


Researchers in the four domains of language use are the family domain, the area of neighbors, the sphere of education, and the religious domain, using the "every time" language factor in Balinese language as one of the highest values in the form of loyalty of ethnic Balinese adolescents in Dangin Puri village against Balinese language. Based on observations, questionnaires and interviews can be identified that the use of Balinese language in the realm of education and religion has a small percentage among ethnic Balinese adolescents who are strongly affected by the use of Indonesian language in the realm of education that provides a sense of comfort in using the Indonesian language and the circumstances carried on almost all domains. Factors influencing the use of Balinese language in Dangin Puri sub-district of East Denpasar, Denpasar city can be divided into 2 (two) that is internal factor, are self factor, interaction factor in family and Factor of interaction with environment and friend Then external factors, are Factors of bilingual speakers' society conditions, Factors of globalization, Educational factors, Indonesian factors

\section{ACKNOWLEDMENT}

I show gratitude to God, and the respondents in the village DangIn Puri, lecturers, tutors, and also fellow who have helped in this study.

\section{REFERENCE}

Brunner, M., \& Ostermaier, A. (2018). Implicit communication in the ultimatum game. Journal of Behavioral and Experimental Economics.

Cainzos-Achirica, M., Bilal, U., Al Rifai, M., Mcevoy, J. W., Blumenthal, R. S., Kapoor, K., Blaha, M. J. (2018). Communication issues in nutritional observational research. Preventive Medicine, 115(March), 76-82.

Cowley, S. J., \& Markoš, A. (2018). Evolution, lineages and human language. Language Sciences, 1-11.

de Bruin, A., Samuel, A. G., \& Duñabeitia, J. A. (2018). Voluntary language switching: When and why do bilinguals switch between their languages? Journal of Memory and Language, 103(January), 28-43.

Fisman, D. (2018). Inferring regular languages and $\omega$-languages. Journal of Logical and Algebraic Methods in Programming, 98, 2749.
Gamallo, P., Pichel, J. R., \& Alegria, I. (2017). From language identification to language distance. Physica A: Statistical Mechanics and Its Applications, 484, 152-162.

Gobbo, F. (2017). Are planned languages less complex than natural languages? Language Sciences, 60, 36-52.

Goriot, C., Broersma, M., McQueen, J. M., Unsworth, S., \& van Hout, R. (2018). Language balance and switching ability in children acquiring English as a second language. Journal of Experimental Child Psychology, 173, 168-186.

Hanson, T. A., \& Olson, P. M. (2018). Financial literacy and family communication patterns. Journal of Behavioral and Experimental Finance.

Hauck, J. D. (2018). The origin of language among the Aché. Language and Communication, 113 .

Henderson, K. I. (2017). Teacher language ideologies mediating classroom-level language policy in the implementation of dual language bilingual education. Linguistics and Education, 42, 21-33.

High, C. (2018). Bodies that speak: Languages of differentiation and becoming in Amazonia. Language and Communication, 1-11.

Hölzl, R., Jain, S., \& Stephan, F. (2018). Learning pattern languages over groups. Theoretical Computer Science, 742(June 2017), 66-81.

Irtza, S., Sethu, V., Ambikairajah, E., \& Li, H. (2018). Using language cluster models in hierarchical language identification. Speech Communication, 100(January), 30-40.

Jin, Y., Austin, L., Eaddy, L. S., Spector, S., Reber, B., \& Espina, C. (2018). How financial crisis history informs ethical corporate communication: Insights from corporate communication leaders. Public Relations Review, (June), 0-1.

Kridalaksana, H. (1982). Kamus Linguistik. Jakarta: PT. Gramedia.

Li, B., Liu, H., Pérez, A., \& Xie, N. (2018). Cathodal transcranial direct current stimulation over right dorsolateral prefrontal cortex improves language control during language switching. Behavioural Brain Research, 351(May), 34-41.

Li, C., Jiang, G., \& Dewaele, J. M. (2018). Understanding Chinese high school students' Foreign Language Enjoyment: Validation of the Chinese version of the Foreign Language Enjoyment scale. System, 76, 183-196.

Mason-Apps, E., Stojanovik, V., Houston-Price, C., 
\& Buckley, S. (2018). Longitudinal predictors of early language in infants with Down syndrome: A preliminary study. Research in Developmental Disabilities, (August 2017), 0-1.

Muksin. (2014). Urgensi Regenerasi SDM Pertanian dalam Upaya Mencapai Kedaulatan Pangan. Jember: Politeknik Negeri Jember.

Ohlrogge, A. W., \& Suggs, L. S. (2018). Flu vaccination communication in Europe: What does the government communicate and how? Vaccine.

Raszap Skorbiansky, S. (2018). Investing in communication: An experimental study of communication in a relational contract setting. Journal of Behavioral and Experimental Economics, 74, 85-96. 